Oz Child : Children Australia is an independent, non-government organisation committed to improving the quality of care, life opportunities and status of children throughout Australia by:

- taking or initiating action to protect or enhance the rights of children;

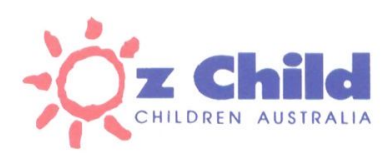

- providing or enabling direct services, through a variety of disciplines, for the benefit of children and their families;

- influencing decisions or actions of individuals, organisations and governments, where relevant to children and their families.

\title{
Oz Child Information Service
}

The $\mathrm{Oz}$ Child Information Service is available, either on subscription or on an 'as needs' basis. It is a comprehensive, efficient and personalised national service designed specifically to meet the information needs of human service professionals, researchers, and students in the child and family area. It provides current information which is targeted, in-depth and easily accessible.

\section{The Collection}

The basis of the Information Service is a specialised collection of over 6000 books, about 280 videos, and approximately 100 journal subscriptions, from Australia and overseas. All books and videos are included on the Information Service database, as are abstracts of all relevant journal articles, forming the basis of a powerful information resource of over 37,000 items. Subject areas include:

- child abuse/protection

- domestic violence

- child/family legal issues

- early childhood

- psychotherapy

- substance abuse
- child rearing/parenting

- family relationships

- child/adolescent psychology

- child health

- family counselling

- education
- children with disabilities

- adoption/fostering

- children's rights

- social policy

- research

- management

\section{The Services}

Access to information is on a subscription basis and, depending on requirements, there are a number of subscription types. Whilst subscribers are welcome to visit the Information Service, most of our services are provided via mail, fax and telephone both locally and interstate.

Nexus is the Information Service's principal vehicle for the dissemination of information. It is published monthly and contains abstracts of at least 200 articles drawn from the current issues of journals, grouped under broad subject categories and including keywords for easy identification of relevant topics. Photocopies of the full text of any articles can be requested. Nexus also contains listings of newly acquired books and videos, which are available for loan.

Database searches are available, either on a subscription basis or as a one-off request, for information on specific topics. The Information Service database includes all books and videos in the collection, as well as the cumulated resource of journal articles indexed for Nexus over many years. Again, full text photocopies of articles can be requested, and books and videos can be borrowed.

To receive further details about the $\mathrm{O}_{z}$ Child Information Service, please complete and return the form below.

Oz Child Information Service

REQUEST FOR DETAILS

Name ......

Organisation.

Address.

Tel:. Fax:

Return to: Oz Child Information Service, PO Box 7020, Dandenong, Vic 3175

Tel: (03) 97921301 Fax: (03) 97921550 
Children Australia is a quarterly journal which aims to provide an opportunity for service providers, academics and others concerned with children and families to report on their work, to raise issues and to share their views.

Children Australia is produced through the cooperative effort of the Editor, the editorial team and the production team, with the cost of production and distribution being met by $\mathrm{Oz}$ Child: Children Australia.

The opinions expressed in Children Australia are those of its contributors and are therefore not necessarily those of the Editor or the publisher. 